\title{
Scrutinizing Individual C- Trans Plus DRTA Method To Increase Student's Reading Comprehension
}

\author{
Mutakhirani Mustafa \\ Ranimanis822@yahoo.co.id \\ FUAD, IAIN Syekh Nurjati Cirebon
}

Received: 13 November 2020 Accepted: 26 November 2020

DOI: $10.24256 /$ ideas.v8i2.1680

\begin{abstract}
The objective of this research is to explain the development Individual C-Trans plus DRTA Method in improving students' reading comprehension at the eighth grade Students of SMP Negeri 40 Bulukumba. The researcher used A Classroom Action Research (CAR) in this research. The researcher had conducted two cycles, where each cycle consisted of two meetings. It employed reading test as instrumen. A number of subject of the researcher were 31 students in XI class. Those consist of 13 men and 18 women. The findings consisted test, students' reading comprehension and observation result. The first cycle of the first meeting was 57,58 and the second meeting was 63,54 and then the researcher tried to do next cycle and the result in cycle II that was increasing of students score. In cycle II of the first meeting was 77,90 and the second meeting was 81,61 . The conclusion of the research using C-Trans plus DRTA is able to improve the students' reading comprehension (main idea) at the eighth grade. It was proved by the students' achievement in cycle II was higher than cycle I and D-Test where in cycle I the students' mean score reading comprehension becomes first meeting was 57,58 and the second meeting was 63,54 , cycle II of first meeting was 77,90 and the second meeting was 81,61. Based on the research findings, the implementation Individual C-Trans plus DRTA Method showed the successful in improving reading comprehension.
\end{abstract}

Keyword: DRTA ; Individual C-Trans; Reading Comprehension 
Mutakhirani Mustafa

Scrutinizing Individual C- Trans Plus DRTA Method to Increase Student's Reading

Comprehension

\section{Introduction}

Everybody knows that reading is one of the language skills which is very important in language teaching and learning process, but it is not easy to do. It is a complex process to learn and complex to teach. The priority of teaching English in school is reading because it can cover the three other skills. Reading is very important in the teaching and learning process because the ability of students to comprehend the subject relatively determined by their reading skill (Mustafa, M., \& Bakri, N: 2020). We can enhance our experience, develop new concept, solve problems, and broaden our knowledge through reading. Reading is an interaction between the reader, the author and the text. The technique of teaching reading is very important to influence the students in reading. A technique can help students in reading, so in teaching English a teacher must use technique or methods where can help the students to comprehends easy what the teacher teach to them. (Ron Fry:1991)

Reading comprehension is not just reading with a loud voice but reading is established to understand the meaning of word, sentences, and paragraph sense relationship among ideas as it is. If a student just reads loudly but cannot understand the content of the text, it means that she/he fails in comprehending the passage. (Ron Fry:1991). This is essence of reading comprehension to comprehend what is read, readers must be able to cognitively process. Cognitive process consists of several processes which are macro-process and elaborative process. Macro-process is the process of reading by summarizing and organizing that can help students easily find the idea or better understand and more easily to remember. Elaborative process is the process of reading that requires predict based on their own experience and knowledge to understand the author's message. (Klinner in Irwin, 2007).

Realizing how important reading, the researcher thinks that it should not be ignored. If everyone concern with it, he or she can enrich his or her knowledge through varied arterials. Therefore, the extrusion of each subject is the command of English reading. Reading takes us out of our country and us. Reading is a process, which helps one to understand the world. By reading we can broaden our horizons and gain new information.

Based on the diagnostic test, if short that the result of the students' achievement especially in reading at the eleventh grade students of SMPN 40 Bulukumba was still low. The score mean 5.39, these score was classified as poor. In this study, the researcher wished to solve this reading problem until the students have a good score between 7.0-8.0. Therefore, the researcher gave a solution about the problem with Transactional Instruction. C-Trans (Creative-Transactional Instruction) is one of method in using cooperative learning. C- Trans was not able to improve students' reading comprehension without combination with other method. The modern method was able to implement wit C-TRANS that was DRTA. 
ISSN 2338-4778 (Print) ISSN 2548-4192 (Online)

Based on the findings of Ginting, D. A ( 2019) in his research, the finding was positive an effect of the DRTA (Directed Reading Thinking Activity) method on the student's reading comprehension. DRTA had giving the contribution to improving students' reading comprehension even though it was not significant result to help the students in reading comprehension. According to Almanza, T. (1997) found that the finding indicated that the majority of students in the cooperative reading groups got higher score on their reading comprehension tests than when they implemented the DRTA. From the research, using DRTA is not enough to help the students in improving reading comprehension. It needs combination with other method to make variety in reading activity. Hasan, A. (2018) in his research found DRA method contributed the effect of improvement on students' reading comprehension. The implementation of this DRA method was without activity but it was giving the big constribution to increase the students' reading comprehension. Next research is coming from Hasan, A. (2017), the findingis a significant effect of using Directed Reading Thinking Activity

(DRTA) method on students' reading comprehension. The lack of this method was time of teaching the class because most of the students needed a lot of time to understand of the instruction from the teacher. In other researcher coming from Nerim, N. (2020). The results of the research showed that the DRTA strategy in teaching reading had a more positive effect than the conventional learning strategy. DRTA is one of the modern method that it has not been popular in teaching reading scope. Based on many researches about the effectiveness DRTA in improving reading comprehension, mostly the teacher implemented that method even thought they found many obstacle to achievement the good result .

Based on the some research of the effectiveness of using DRTA in reading comprehension above, that method totally needs C-Trans (Creative-Transactional Instruction) to make completed in improving students' reading comprehension. C-TRANS is long term, with the theory being that sophisticated thinking processes are developed through long-term interactions with other. C-Trans (Creative-Transactional Instruction) consist of: prediction of upcoming content; visualization (constructing mental images representing the ideas represented in the test being read); making connection to prior knowledge); asking oneself question about the text; seeking clarification when confused; and summarizing activities". It works to combine with DRTA method to show the fast result in improving students' reading comprehension. DRTA is Directed Reading Thinking Activity that is one of the modern method in reading.

Related to the background, the researcher formulated a research questions as follow "What is the effective ways of applying C-Trans (Creative-Transactional Instruction) plus DRTA to improve the students' reading comprehension of the students at eight grade of SMPN 40 Bulukumba?" 


\section{Method}

In this research, the researcher implemented Classroom Action Research ( CAR ). Hopkins (2008) the argue the model of action research is the design of the research can be used to translate a the concept into the reality that are more practical. The researcher aimed to find out the students' elaborative process and macro-process in applying of the using C-Trans (Creative-Transactional Instruction) plus DRTA to teach reading comprehension at the eleventh grade students of SMPN 40 Bulukumba. The researcher divided into two cycles with each cycle consisted of four phases. Each cycle consisted of planning, action, observation and reflection.

The first step before research, the research did observation and got some data about the students condition in the class, which students' problem. The research got information which they are difficulties to be a good reader. Most of them had a good score in reading comprehension but not all of them understand or comprehend the text. The teacher often gave them text and got the students to make them comprehend and most of them did it. The data was analyzed to overcome the problem. It means that the students need new technique how to be a good reader. The researcher gave a technique, namely C-Trans (Creative-Transactional Instruction) plus DRTA method which this method helped the students to understand or comprehend test.

The purpose researcher observation in teaching learning process is to improve the students reading skill. The researcher ask to students that they will practice as they prepare for carry out a text in reading skill. The explanation and procedure text was using as researcher us as atext to improve reading comprehension. The researcher choose narrative as text the researcher adjust with school material in reading comprehension. The researcher gave material and test and also time about the situation class during 30-45 minute. The researcher take enough time to test because to understand the text is not easy. The students read the text and made connection with each other idea in text. The teacher asked students to give prediction and explanation about the text where the other students understood their friend's explanation. After that the teacher asked them to make summarize it.

The researcherwas using short story as a media where they had some reason which suitable with the previous related finding, namely :

1. Media can overcome the limited experience had by learners

2. Media can get students interest

3. Media can overcome the classroom

4. Media can give direct interaction between learner and their surroundings

5. Media can result the homogeneous observation

6. Media can give right base concept, concrete and real

7. Media can improve new interest and desire

8. Media can motivate and stimulate learners 
9. Media can give the integral experience from the concrete to the abstract.

The researcher was used two cycle in classroom action research , namely:

1. First Cycle

Based on the analysis from the students test in cycle I, the mean score at the first meeting was 57,58 that it was low score by the standard of score. The students got a low score because Individual C-Trans plus DRTA Method still was new instruction to the students in reading comprehension. The students need habit to know the new method and the important thing to understand Individual C-Trans plus DRTA Method was how the students understood the each paragraph of the text. If the most students have understood the meaning text automatically, They quickly understood C-Trans plus DRTA method so they knew how to fill the C-Trans chart. Mostly the students needed time to understand the instruction and the step of this method to show the high achievement .

At the first cycle of second meeting was 63,54 that the result showed the increasing score then the first meeting but still low score even almost reaching the standard score. This was increasing score than before which showed that the students need habitual to understand a new method. Understanding short story needed connection, prediction, clarification and summarizing. In the first meeting, students still adapted to the method because it was new step and new activity in reading activity. Furthermore at second meeting showed the improvement of the score, they got increasing score so it indicated the effect of the implementation of the method.

From the students' attitude in learning reading comprehension process by classroom observation technique relating to data a analysis based on the test, The showed the positive attitude. It was considered that the method was not improving the achievement of students score in reading comprehension but also it was effect to the students' attitude. The researcher presented the students attitude in learning process in first cycle was low interest. It was found that there were 3 students very active, 7 students active, 16 students less active, 5 students not active.

2. The Second cycle

Based on the analysis the students test in cycle 2, the mean score in the second cycle of the first meeting was 77,90 that it was the increasing score than first cycle but still low standard score. In this cycle showed the significant effect to the students score. The different score in second cycle of second meeting 81.61 was the increasing score then the first meeting in second cycle and first cycle. The achievement was reaching the standard score then cycle 1 . it means that it was a good score.

Based on observation activities made by researcher and observer in the first cycle, the researcher used ways in learning process, they were giving some motivational words be active in learning process, and how important the English reading comprehension, give opportunity the students to reading comprehension it 
meant that to made students more pay attention and made understand, give the students opportunity to understand difficult word to make easy text comprehension. This is showed that this way in second cycle made students got increasing score. It means that the students have good understand the text in learning reading comprehension.

The students' attitude in learning reading comprehension process by classroom observation technique relating to data analysis based on the test, the researcher presented the students attitude in learning process in second cycle was interested to the lesson. It was found that there were 8 students vary active, 17 students active, 6 students less active, none students not active. It showed that the students more active after implemented this method. Moreover it showed that the students have understood to implementation C-Trans (Creative-Transactional Instruction) plus DRTA method.

Many the finding of the research showed the positive effect of DRTA in teaching reading. One of them is from Hasanah, U. (2016). It could be concluded that the implementation of DRTA with cooperative learning was effective to improve students' reading comprehension achievement. This research showed that the successful of the combination the method and the strategy in teaching reading. Other finding of the research is from Utami, Y. P., \& Sugirin, S. (2019). In the finding, the researchers believed that DRTA strategy was given more contribution in improving students' reading comprehension. The researcher implemented the method without combination or addition method but it still showed the effectiveness even thought the result was not significant. Next finding of the research is from Ismail, M. (2018). In his research, the researcher found the effectiveness DRTA method in improving students' reading comprehension. Mostly the researcher have done implemented DRTA method in improving students' reading comprehension even thought the contribution was not helping the students at all in reading comprehension. This method needed the innovation to make more effective in teaching reading in other the researcher implemented C-Trans (Creative-Transactional Instruction) plus DRTA.

This method is not the newest in teaching reading but the combination two methods in implemented to the class were the newest innovation because the research applied two methods to be one in teaching reading. This was the new innovation in teaching reading and it showed the positive effect to the students. So the result of this research was indicated that C-Trans (Creative-Transactional Instruction) plus DRTA method was succeed to improve students' reading comprehension.

\section{Conclusion}

Using C-Trans (Creative-Transactional Instruction) plus DRTA method is able to improve the students' reading comprehension (main idea) at the eighth grade. It was proved by the students' achievement in cycle II that the result was 
greater than cycle I and D-Test where in cycle I the students' mean score reading comprehension becomes first meeting is 57,58 and the second meeting is 63,54 , cycle II of first meeting is 77,90 and the second meeting is 81,61 . Using C-Trans is able to improve the students' summarizing it was proved by the students' achievement in cycle II is higher than cycle I.

Using Individual C-Trans plus DRTA Method is able to improve the students' reading comprehension that it was proved by the students' achievement in in cycle II is higher than cycle I. Where the cycle I mean score is the first meeting is 57,58 and the second meeting is 63,54 after evaluation in cycle II the students' conclusion become of the first meeting is 77.90 and second meeting is 81,61 . Using Individual C-Trans plus DRTA Method was able to make the students more active in learning process, especially in reading activities. The process of the teaching and learning well ran during the classroom action research at the eighth grade because the students were having spirit and fun studying English. Besides that, the researcher also got full support and motivation by the teachers.

For suggestion to the next researcher, Individual C-Trans plus DRTA Method is giving references to many researchers that the innovation in teaching process needed to help the students. So the next researcher may conduct research to a method with innovation and combination with other method in teaching reading. they may take the other case of reading to be improved neither they use this method nor other methods. But it is better to use this method in order to know the improving students' reading comprehension by different discussions.

\section{References}

Almanza, T. (1997). The Effects of the DRTA and Cooperative Learning Strategies on Reading Comprehension. Master Thesis, Kean College New Jersey

Brassell, D and Rasinski, T. (2008). Comprehension that Works. Huntington Beach: Shell Education

Brown, R. (1994). The Evolution of Transactional Strategy Instruction in One Teachers Classroom. Journal National Reading Research Center, ED 375389 No.19

Burns, A. (2010). Doing Action Research in English Language Teaching. New York: Routledge

Christen, W. (1991). Increasing Comprehension by Activating Prior-Knowledge. Journal ERIC Clearinghouse, ED 328885

Duckworth, Fred W. (2010). Integrating Reading Comprehension.Jewels Educational Services For Up-And-Coming Scholars

Fry, Ron. (1991). Improve Your Reading.Singapore : SSMB A Publishing Division

Ginting, D. A. (2019). The Influence Of DRTA (Directed Reading Thinking Activity) Method on the Students' reading Comprehension At SMA Taman Siswa Binjai. Jurnal Sintaksis Available online at, 1(1).

Hasan, A. (2018). The effects of DRA and DRTA methods on students' reading 
Scrutinizing Individual C- Trans Plus DRTA Method to Increase Student's Reading

Comprehension

comprehension for state Islamic senior high school. American Journal of Educational Research, 6(3), 281-287.

Hasan, A. (2017). The Effect of Directed Reading Thinking Activity (DRTA) Method on Students' Reading Comprehension for State Islamic Senior High School. Journal of English and Arabic Language Teaching, 8(2), 140-148.

Hasanah, U. (2016). Directed Reading Thinking Activity (DRTA) on Students'reading Comprehension . Doctoral dissertation, Lampung University.

Hopkins, David. A Teacher's Guide To Classroom Research. USA : McGraw Hill-Open Univeresity Press. 2008.

Ismail, M. (2018). The Use of Directed Reading Thinking Activity (DRTA) to Improve Students Reading Comprehension of the First Grade of Smk Pembangunan Kota Ternate. LANGUA: Journal of Linguistics, Literature, and Language Education, 1(1), 42-48.

Israil, E Susan. (2008). Metacognition in Literacy Learning. New Jersey: Lawrence Elboum Associates

Klinner, Jenette K. (2004). Teaching Reading Comprehension to Stı ' ' with Learning Difficulties. London: The Guilfdord Press)

Koshy, Valsa. (2005). Action Research for Improving Practice. London: Paul Chapman Publishing

Lakshmi, Leiglneni B. (2006). Reading and Comprehenion. Delhi: AororaOffet Press

Macceca, Stephania. (2007). Reading Strategies for Science Grades 1-8. United Kingdom: Shell Education

Masruddin, M. (2016). The Efficacy of Using Language Experience Approach in Teaching Reading Fluency to Indonesian EFL Students . Arab World English Journal,7 (4). DOI: dx.doi.org/10.24093/awej/vol7no4.21

Mckeough, Anne. (1995). Teaching for Transfer. New Jersey: Lawrence Elboum Associates

Mustafa, M., \& Bakri, N. (2020). Analyzing the Level of the Students' reading Comprehension in Comprehending the Narrative Text. Acitya: Journal of Teaching and Education, 2(2), 152-161.

Nerim, N. (2020). Scrutinizing Directed Reading Thinking Activity (DRTA) Strategy on Students' reading Comprehension.JOLLT Journal of Languages and Language Teaching, 8(2), 128-138.

Pressley. Michael. (1994). Transactional Instruction of Reading Comprehension Strategies. Journal National Reading Research Center, ED 375391 No.5

Phillips, Donna Kalmbach. (2006). Becoming a Teacher through Action Research. New York: Routledge

Rohim, Fathur. (2009). Teaching Reading. Jakarta: Center for Development and Empowerment of Teachers and Education Personal

Rusdiansyah, R. (2019). Note-Taking as a Technique in Teaching Reading Comprehension. IDEAS: Journal on English Language Teaching and Learning, $\begin{array}{lll}\text { Linguistics and Literature, } & \text { 7(2). }\end{array}$ 
doi:https://doi.org/10.24256/ideas.v7i2.1033

Simanjuntak, (1998) .Developing Reading Skill for EFL Students. Jakarta: Depdikbud

Schunk, Dalle H., and Zimmeriman, Barry J. 1998.Self-Regulated learning. New York: The Guilford Press

Sukiman. (2010) .Improving Reading Comprehension through Preview, Question, Read, Self-Recite, and Test (PQRST) Strategy. Unismuh: Makassar

Soedyarto, N. (2008). Matematika Untuk SMA dan MA Kelas 2. Jakata: Departemen Pendidikan Nasional

Sweet, A. P. (2003). Rethinking Reading Comprehension. New York: The Guilford Press

Utami, Y. P., \& Sugirin, S. (2019). Fostering Students' Reading Comprehension Ability through Directed Reading Thinking Activities (DRTA) Strategy. Journal of English Language Teaching and Linguistics, 4(2), 129. 